\title{
Impact of Budget Deficit on Nigeria's Macroeconomic Variables: 1980-2012
}

\author{
Chukwu L.C Phd ${ }^{1}$, Otiwu K PhD ${ }^{2} \&$ Okere P.A. ACIB ${ }^{3}$ \\ 1. Dept. of Accountancy, Imo State University, Owerri \\ 2. Dept. of Banking and Finance, Imo State University, Owerri \\ 3. Dept. of Banking and Finance, Imo State Polytechnic, Umuagwo-Ohaji
}

\begin{abstract}
This study investigated the impact of budget deficit on macroeconomic variables of Nigeria, covering the period, 1980-2012.The study was informed by the need to solve the problem of ever-increasing huge budget deficit in the face of weak economic growth and macroeconomic performance. Employing the two stage least square, data analyses were carried out to cover the unit root, granger causality and co integration tests to produce five statistically significant models viz-a viz the budget deficit and economic growth model, the budget deficit and real interest rate effect model, the budget deficit and inflation rate effect model, the budget deficit and investment effect model, and the budget deficit and real exchange rate effect model. It was found out that budget deficits have significant negative relationship with gross domestic product growth rate, real private investment, inflation rate, real exchange rate and positive significant relationship with real interest rates. Thus, the study concludes on the basis of these findings that budget deficit financing has not engendered the required growth in the Nigerian economy and therefore should be reduced.
\end{abstract}

Key words: Budget deficit, macroeconomic variables, Inflation

\section{INTRODUCTION}

Budget is an important tool for managing an economy. It is also a key instrument of fiscal policy in Nigeria (Onuorah and Odita, 2013). A budget deficit which is the excess of expenditure over the revenue accruable to the government arises from the fiscal operations of the government. The use of the fiscal policy by the government focuses on the way the expenditures and revenues would be utilized for a given period. The primary objective of budget deficit in Nigeria could be seen as achieving efficient distribution of the natural resources and income between the public and private sectors. One of the most important aspects of fiscal policy is the management of the public sectors' fiscal deficit.

Hence, public sector borrowing gives an estimate of the volume of fiscal deficit. Large and persistent fiscal deficit has become characteristic of most less developed countries. It is caused basically by tremendous upward movement in the expenditure variables on the one hand, and sluggish growth of revenue on the other hand (Nwaogwugwu, 2005). While the former can be traced to the strong desire of the government to upgrade the social overhead capital and the quest for as well as lack of or stagnant economic growth and thereby constraining the taxable capacity of the resource bases. This is because it is widely recognized that fiscal deficits - a key fiscal indicator and macroeconomic indicators (like growth, inflation, the current account, etc) influence each other in both directions (Anyanwu, 2002).

In Nigeria and like many countries of the world budget deficits can be financed by borrowing from the central bank (deficit financing and money creation), borrowing from the domestic money market (mainly from the banks) and borrowing from abroad (Chima, 2012). One of the most important objectives of fiscal policy is to reduce national debt and to check the interest payment of such debt from rising and to prevent it from leading to higher deficits in the future. However, what is common with most economies, especially developing ones, is that even with stream-lined budgets, the expected revenue often fails to support intended expenditures. Hence, the government of the day is faced with the financing of this shortfall through Deficit Financing.

Thus, government reliance on the banking system to finance its deficits in the latter years impacted negatively on macroeconomic variables as manifested in high monetary expansion, high inflationary pressures, low real growth rate, deterioration in the balance of payments and exchange rate depreciation (CBN 2010).There 
are four major ways of financing budget deficits: (a). domestic borrowing, (b) foreign borrowing, (c). raising of reserve requirements which occurs when banks are made to hold additional required reserves as cash balance with the central bank or eligible government securities.

Each of these financing modes has deleterious effects on the economy.

\section{Statement of the Problem}

Budget deficit financing has many implications for the macro economy. These implications depend on the level of employment in the economy. When the employment is full, excessive budget deficits is likely to bring about macroeconomic imbalances. It will adversely affect output, growth and raise inflationary pressures in the economy (Agbiokoro, 2010). This is true because it increases the reserve base of deposit money banks, which creates excess liquidity in the financial system.

If the deficits are channeled into investments in productive activities such as capital goods, training or new technology, the economy might grow faster than the burden of the debt. This is because the investment will lead to long-term growth. Therefore deficits could lead to the achievement of macro economic stability and growth. This condition, according to Gbosi (2004) holds if the size of the overall deficit is about 3 percent of the Gross Domestic product (GDP).

Available evidence shows that many of the years under review (1980-2010), Nigeria's fiscal operations have resulted in continuous overall budget deficit . Out of the 34 years under review; Nigeria recorded 32 years of budget deficits. Economic activities are meant to be accelerated with budget deficit financing through induced aggregate demand. The question is, has deficit financing exercebated the problem or helped to reduce the problem?

Despite the fact that Nigeria has been operating budget deficit financing over these years she still finds herself in a situation of low employment, economic distress, fall in standard of living, decline in the growth of the economy, increased public debt, balance of payment problem, continued depletion of the foreign reserve, little or no savings, decline and over dependence on oil exports, increased inflationary pressures, real exchange currency pressures, continuous dependence on external economies etc.

\section{The Objectives of the Study}

This study has as its central objective of the determination of the impact of deficit on the Nigeria's Macroeconomic variables. Specifically, the study is intended to accomplish the following objectives;

i. To determine the effect of budget deficit on economic growth in Nigeria.

ii. To determine the effect of budget deficit on interest rate in Nigeria.

iii. To determine the effect of budget deficit on the inflation rate in Nigeria.

iv. To determine the effect of budget deficit on investment in Nigeria.

v. To determine the effect of budget deficit on exchange rate in Nigeria

\section{Research Questions}

Considering the objectives of this study, the following research questions are therefore raised for the study;

i. To what extent has budget deficit affected economic growth in Nigeria?

ii. What is the influence of budget deficit on the level of interest rate in Nigeria?

iii. To what extent has budget deficit affected the inflation rate in Nigeria?

iv. How has budget deficit affected the level of investment in Nigeria?

v. To what extent has budget deficit affected exchange rate in Nigeria?

\section{Research Hypotheses}

Having stated the above objectives and research questions the following research hypotheses are therefore formulated to guide the study:

$\mathbf{H}_{\mathbf{0} 1}$ : The level of budget deficit does not affect economic growth in Nigeria.

$\mathbf{H}_{\mathbf{0} 2}$ : The level of budget deficit does not significantly affect the level of interest rate in Nigeria.

$\mathbf{H}_{\mathbf{0}}$ : The level of budget deficit does not significantly affect the level of investment in Nigeria. 
$\mathbf{H}_{\mathbf{0} 4}$ : The level of budget deficit does not significantly affect inflation rate in Nigeria.

$\mathbf{H}_{\mathbf{0} 5}$ : The level of budget deficit does not significantly affect the level of exchange rate in Nigeria.

\section{Review of Related Literature Conceptual Literature}

Budget deficit arises when the revenue and past accumulation of past savings become inadequate to finance the expenditure gap still left on the current and capital accounts (Ogboru, 2010. Government budget deficit in any given economy can be financed by using monetary finance and debt finance. Monetary financing of a budget deficit has to do with printing (creation of money) of currency by the monetary authority, the revenue accruing from which is called 'seigniorage'(Jhingan,2004; Nzotta, 2004; Ogboru,2010). In this situation, the government offers in the market a stock of money that exceeds the amount objectively justified to be in circulation in the economy.

\section{Deficit Financing and Inflation}

The persistent government budget deficits and government debt have become major concern in both developed and developing countries (Awe and Shina, 2012).The rate of inflation has been on the increase with its damaging effect on the economy through the movement of price of consumer's goods and services (Awe and Shina, 2012). When there is a budget deficit, government finds ways to finance the deficit through borrowing from commercial and merchant banks or from the non - banking public and through the issue of short- term bonds and monetary instruments, and external borrowings (Isenmila, P.A and Okolie, A. O, 2008). According to them, the use of deficit financing for the pursuit of fiscal policies often leads to increased danger in an economy.Inflation remains one of the major economic variables that can distort economic activities in both developed and less developed Countries (Adenuga, Taiwo and Efe, 2010).

Generally, low and stable inflation has become the core mandate for most central banks across the globe for the obvious reason that inflation has costs on the economy (Mordi, 2009). In a developing country like Nigeria, where capital and financial markets are largely underdeveloped, a high rate of inflation results in the movement of portfolio investment from real money to real assets (Ukeje, Essien, Yakubu and Akinboyo, 2004).

\section{Theoretical Literature}

The relationship between budget deficits and macroeconomic variables (such as growth, interest rates, trade deficits, exchange rate, price level, investment among others) represents one of the most widely debated topics among economists and policy makers in both developed and developing countries (Saleh, 2003). These their constrasting views seem to have made less attractive the use of fiscal policy in stimulating economic activity (Agbiokoro, 2010).The emergence of any macroeconomic instability depends on the way and how budget deficits are financed. There exist three distinct theories on the relationship between budget deficit and macroeconomic variables; Keynesian, Neoclassical and Baro - Richardian theories.

\section{Keynesian Theory of Deficit Financing}

The Keynesian theory states that government spending enhances economic growth (Appiah and Chigbu, 2013). Okpanachi and Abimiku (2007) reported that budget deficit stimulates economic activities in the short run by making households feel wealthier, hence raising total and public consumption expenditure. Keho (2010) stated that budget deficit has a positive effect on macroeconomic activity, thereby stimulating savings and capital formation.

\section{Neoclassical Theory}

This theory states that government budget deficits constitute merely a transfer of resources from the private sector to the public sector with little or no effect (Ahmad and Miller (2000), Saleh, (2003), Dalyop,( 2010). They also stated that since the private sector is more efficient than the public sector, such a transfer could have a negative effect.

\section{The Baro-Ricardian Theory}

To analyze the effects on the economy of the government's choices between raising taxes and debt issuing, we start from the radical Ricardian vision, which posits the irrelevance of the government's financing 
decisions (Romer, 2001). According to the Ricardian equivalence theorem, 'substituting debt issuing for taxation does not make any difference for the real state and development of the economy' (Van Velthoven, Verbon and Winden, 1993); regardless of whether government spending is financed through increasing taxes or issuing new bonds, the effects on the economy will be same.

This Ricardian equivalence theorem, also called the "Baro neutrality result" has two important implications. First, a household's consumption falls when government expenditures increase, whether they are deficit - financed( with the same current disposable income but increased private savings) or financed through taxation with less current disposable income). Similarly, a deficit - financed cut in current taxes doesn't affect a household's consumption, as families are left with more current disposable income but start saving more, and the second effect offsets the first one. Consequently, households are perfectly indifferent to choosing between debt and financing, and a shift from tax to bond finance does not affect current consumption.

\section{The Crowding out Theory}

The liquidity - constrained thesis (that is (crowding-out thesis) maintains that external debt is negatively correlated with growth in that resources to service the debt reduce the amount available for investment purposes. Thus both the debt overhang thesis and crowding out thesis suggest strong negative effect of debt on growth. An indebted country is most likely to face credit constraint, which is the same as facing higher real interest rates, which discourages investment. Rising interest rate and inflation worsen the macroeconomic environment and hurt investments.

Crowding out is one of the potential consequences of deficit financing. When the government borrows funds to finance the deficit, the availability of funds for private sector spending may be reduced. Simply put, funds that would have been borrowed by the private sector are transferred to the government (Adeyusi and Falowo, 2013).

\section{Budget Deficits and Economic Growth}

The role of expansionary fiscal policy on economic growth has generated series of intellectual brainstorming on whether a prolonged budget deficit induces or reduces national output particularly in the developing countries. The outcome probably depends on how the deficit is being financed and its distribution between capital and recurrent expenditure (Umaru and Gatawa, 2014)'.

Budget deficit has become a striking and institutionalized feature of Nigerian economy. The principal issues of budget deficits are not new in Nigeria and this has taken place for more than three decades. Government fiscal operation is recognized as a tool for economic management and plays a vital role in stimulating economic growth (Odhiambo, Momanyi, Othuon and Aila, 2013). Large budget deficits have considerable effect on national savings and could crowd out private investment. The crowding out is brought through higher interest rates as firms that want to borrow for investment projects compete for that smaller pool of available funds. In the process, they bid up the interest rate that they are willing to pay. The higher interest rates dissuade some firms from undertaking their investment projects, with net results that investment declines growth (Pechman, 2004). An important feature of government borrowing is that it is insensitive to interest rates. That is, the government will borrow whatever it needs to finance its deficit no matter what the interest rate because its budget deficits are always financed. As a result, deficits reduce the funds available for capital formation (Odhiambo, et al, 2013).

Generally, the relationship between budget deficits and growth revolve over three pertinent issues such as: excessive domestic borrowing by the government which crowds out private sector investment and push up interest rates; the accumulation of public debts; and the fear that the government may resort to money printing or 'seignorage', thus resulting in inflation. These effects operate through three channels: First, high budget deficits may lead to higher real interest rates in the financial markets, which may reduce investment and growth. Second, high deficits may increase risk premiums on interest rates, particularly raising the inflation risk and default risk premium. High interest rates risk premiums may discourage investment. Third, high budget deficits may signal a high tax burden in future, which may discourage aggregate expenditures and therefore private investment (Hermes and Robert, 2001). Baldacci, et al, 2003) reported that fiscal policy has to be tailored to country - specific condition to foster growth. Maji and Achegbulu, 2012) see economic growth as annual percentage increase in Gross Domestic Product (GDP). 
Most developed countries are less faced with the problem of budget deficit due to their strong fiscal structure while their developing counterparts are seriously faced with it (Sahan and Bektasogh, 2011). This may not be unconnected with unstable public revenue, economic underdevelopment, deficient government authority, high inflation and low per capital income that all characterized the developing economies. Budget deficit can be financed by printing money, running down foreign exchange reserves, borrowing from abroad and domestic markets. Each of these sources has its own implications on the macroeconomic variables of the concerned economy (Sahan and Bektasogh, 2011).

\section{Budget Deficits and Interest Rates}

It is the price which equilibrates the desire to hold wealth in the form of cash with available quality of each that is the price of credit (Ezeabasili and Mojekwu, 2011). The relationship between budgets dated back to Mundel -Flemming which assumes that an increase in budget deficit causes an increase in interest rate with exchange rate appreciation and capital inflows (Odionye and Uma, 2013). Despite the theoretical link between budget deficit and interest rate, there is no general consensus between them (Odionye and Uma, 2013). Two diverging viewpoints exist, namely, the Ricardian Equivalent hypothesis (REH) and the Conventional Keynesian proposition (CKP). According to Ricardo, budget deficit does not matter, because an increase in government budget deficit is effectively equivalent to a future increase in tax liabilities. Believing that lower taxation in the present is offset by higher taxation in future, it means that budget deficits do not influence the macroeconomic variables.

Despite and given the relationship between budget deficit and interest rate, the alleged interactions between the two variables in the economy of Nigeria are still not obvious from the trend evidence, and this remains unclear despite the fact that this study has already been investigated intensely. Arguably, inconclusiveness originates from the composition of the composed kind of empirical studies, considering different data and estimation techniques used in Nigeria and other economies of the world (Odionye and Uma, 2013).

\section{Budget Deficits and Investments}

The large budget deficit brings about surge of interest rate and precipitates a decline in domestic private investment (Edeh and Obi, 2014). According to Ezeabasili and Nwakoby (2013), several studies have dealt with the effect of fiscal deficit, either by testing for the Keynesian proposition or the Ricardian equivalence hypothesis. Most of these studies cover developed countries and other contexts different from Nigeria. Such studies include Chete and Akpokodje (1997); Rama (1993); Solamano (1993); Erden and Hocombe (2005); Blejar and Khan (1994); Albatel (2004); Hoelscher (1993) are replete in the literature. Public investment or public capital, public deficits, corporate tax and investment incentives, and the user cost of capital or real interest rate are four major channels through which fiscal deficits affect private investment (Ezeabasili and Nwakoby, 2013).

\section{Budget Deficits and Exchange Rates}

Macroeconomic policy is in the realm of normative and prescriptive macroeconomics. It involves the manipulation of a number of policy instruments including fiscal (Revenue and Expenditure) and monetary (Exchange rate) policy instruments (Kalu, Metu and Nwachukwu, 2012). The exchange rate is a key macroeconomic variable in the context of general economic policy making and of economic reforms, in particular (Obadan, 2006). The current exchange rate regime in Nigeria is the off shoot of structural adjustment programme adopted by the former military head of state, General Babangida. Under the structural adjustment programmes in Nigeria which was implemented from July 1986, the exchange rate strategy was to float the Naira and establish an institutional framework for its trading in a market - determined environment, accordingly, a market determined exchange was established and exchange rate policy objectives pursued within the institutional framework of the second - tier foreign exchange market (SFEM), (Obadan, 2006).

\section{Empirical Literature}

Omoninyi, O.S, Olasnkanmi, O. I, and Babatunde, O. A (2012) examined the effects of twins' deficits in Nigeria from 1970 - 2008, using secondary time -series data and analysis and econometric techniques. The results showed that there was a bidirectional causality relationship between budget deficits and trade deficits in 
Nigeria. Mendee and Nenbee (2012) examined fiscal deficits and inflation in Nigeria for the period of 30 years, starting from 1980 to 2010. The study employed econometric technique, using Ordinary Least Square (OLS) estimation method of multiple regression. The analysis showed that both inflation rates and interest rates were rightly signed with fiscal deficits.

However, the evidence by Gemmel (2001) from low income, medium and high income countries contradicts most of the earlier evidences on the impact of budget deficits on growth. The result revealed significantly negative effect of budget deficit on economic growth. Perott (2004) studied five OECD countries on the effects of fiscal policy on GDP. The result revealed that the effect of fiscal policy on GDP tends to be small, and the effects of government spending shocks and tax cuts on GDP and its components have become subs tantially weaker over time. M'Amanja and Morrissey (2006) concluded that unproductive expenditure and non-distortionary tax revenue were found to be growth predicted by economic theory.

Audu (2012) examined the relationship between money supply, fiscal deficit and export on economic growth from $1970-2010$ using error correction mechanism. His findings indicated that all the variables have significant impact on economic growth. Nurudeen and Usman (2010) studied the relationship between government expenditure on health, transport and communication and economic growth. The findings revealed that government expenditure on health coupled with transport and communication related expenditures as inducing economic growth positively while capital expenditure, recurrent expenditures, as well as a disaggregated expenditure on education being negatively related to economic growth.

Wosoweil (2013) examined the relationship between fiscal deficit and some macroeconomic aggregates in Nigeria for the period 1980 - 2010, using ordinary least square (OLS) and Engel Granger cointegration approach. The result revealed a negative but insignificant relationship between fiscal deficit and Gross Domestic Product (GDP). Usman et al (2011) studied the relationship between government spending and economic growth, using vector error correction model. The result revealed the existence of a long-run relationship between government spending and economic growth. Taiwo and Abayomi (2011) studied the relationship between economic growth and capital and recurrent expenditure, using ordinary least square (OLS) On series from 1970 to 2008. They found a significant positive relationship between economic growth and capital and recurrent expenditure.

Odionye and Uma (2013) empirically examined the relationship between budget deficit and interest rate in Nigeria, using vector error correction model (VECM) for the period of 1970 to 2014. They reported that in the long run, budget deficit showed a positive and significant impact on interest rate, implying that a high budget deficit will increase interest rate in Nigeria. The studies of Laubach (2003); Canzoneri et al (2002); Shapiro (2004) suggested that rising interest rates are associated with federal deficits. Also, Gale and Peter (2003); Dai and Philippon (2004); Kimberly (2008); Patnaik (2000 and 2001); Deepak Lal et al (2001) reported that the financing of large fiscal deficits has led to higher interest rates and crowds out private investments.

Some studies did not support the view that large deficits and debt raise interest rates (Elmendorf and Markiw, 1993). Other authors include Chakraborty (2002); David et al (2003); Kirchner (2007); Bebi (2000), Goyal (2004). A lot of empirical studies have been conducted on the relationship between fiscal deficits and private investment over the years. Akpokodje (1998) used a time series data in order to estimate a long run relationship between fiscal deficit and private investment using standard ordinary least squares (OLS) techniques. The result indicated that a fiscal policy weakened by fiscal deficit has a strong and significant adverse impact on private investment in the long run. This negative impact confirms the crowding out effect of government's budget deficit programme on private investment in Nigeria (Obi and Edeh, 2014). Paiko (2004) examined the implication of deficit financing on private sector investment in Nigeria. The study found that a negative relationship exists between deficit financing and investment in Nigeria; and that deficit financing crowds out private investment. Albatel (2004) studied the effect of government budget deficit on the crowding out of private sector investment in Saudi Arabia. The result showed that there is a crowding out of private investment by government budget deficit. 
Adeniyi (2014) empirically analyzed the long -run and short - run effects of budget deficit on investment in Nigeria for the period 1975 - 2010. Employing error correction model and cointegration regression, his study revealed that budget deficit has a significant inverse relationship with investment both in the short run and long run.

The majority of these studies regressed macroeconomic variables on the deficit variable. Some of the studies appear to provide considerable evidence in favour of a relationship between the budget deficit and a certain macroeconomic variable. Moreover, time series analysis allows revealing the causal relationship between variables, while cross section analyses can identify correlation but not causation between variables. It is worth as well that, in general, the key outcomes from the studies presented in this section showed that both the method of financing and the components of government expenditure could have different effects.

\section{Research Methodology}

This study covered the impact of budget deficit financing on the macroeconomic performance of Nigeria, for the period, 1980-2013. The study employed secondary data. The data for the estimation were generated from the websites of the Central Bank of Nigeria (CBN) as well as other publications of the CBN as its statistical bulletin.

\section{Model Specification}

The specification of the model for this study considers the following variable, Real GDP growth rate, Real Exchange Rate, Real Private Investment, Inflation Rate, Real Interest Rate as dependent variables; while Budget Deficit will be used as independent variable.

The model is specified thus:

RGDPgr = f( EXCHR, RPINV, INFLR, RINTR) ...i

Linearizing the model gives

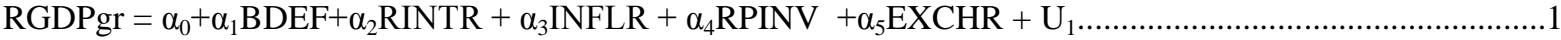

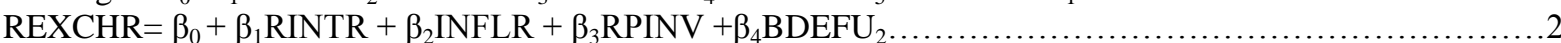

RPINV $=a_{0}+a_{1}$ INFLR $+a_{2}$ REXCHR $+a_{3} B D E F+U_{3} \ldots . .3$

INFLR $=b_{0}+b_{1}$ RPINV $+{ }_{b_{2}}$ REXCHR $+b_{3}$ BDEF $+\mathrm{U}_{4} \ldots . .4$

RINTR $=c_{0}+c_{1}$ INFLR $+c_{2}$ RPINV $+c_{3}$ BDEF $+U_{5} \ldots \ldots \ldots . .5$

Where:

RGDPgr is the Real GDP growth rate;

REXCHR is the real Exchange Rate;

RPINV is the Real Private Investment;

INFLR is the Inflation Rate;

RINTR is the Real Interest Rate;

BDEF is the Budget Deficit

$\alpha_{0}$ is the constant intercept

$\alpha_{1}, \alpha_{2}, \alpha_{3}, \alpha_{4}, \alpha_{5}$ are parameter coefficient of BDEF,

RINTR, INFLR, RPINV, REXCHR respectively.

$\mathrm{U}_{1}, \mathrm{U}_{2}, \mathrm{U}_{3}, \mathrm{U}_{4}, \mathrm{U}_{5}$ are random error terms with white noise properties.

\section{Estimating Techniques}

Two Stage Least Square (2SLS) regression modeling approach involving unit root tests, co-integration and granger causality were employed for this study. Unit root tests were used to test the stationarity of the variables.)

\section{Data Presentation, Analysis and Interpretation.}

As already stated, the data for the estimation was generated from the various publications of the Central Bank of Nigeria. The data set covered figures on Real Gross Domestic Product Growth Rate (RGDPgr), total Budget Deficits (BDEF), Real Interest Rate (RINTR), Real Exchange Rate (REXCHR), Inflation Rate (INFLR), Real Private Investment (RPINV) for the period, 1980-2010. The data sets for this study is in the appendix 


\section{Unit Root and Co- integration Tests}

The unit root test is carried out using the Augmented Dickey Fuller test in order to determine whether the data set is stationary and the order of integration in a time series data. Evidently, from table A and B below, it could be seen that total budget deficits, real exchange rate, inflation and real interest rate were stationary at first difference 1(1), while real gross domestic product growth rate and real private investment were stationary at level 1(0). With the results turning out to be stationary, we then applied the Johanssen co-integration test which adopts no exogenous variables. This helped us in establishing that a strong long-run equilibrium exists between the deficit deficits and economic growth on one hand and on the other hand, between the total budget deficits and selected macroeconomic variables.

Table A: Unit Root Test for Selected Macroeconomic Variables

\begin{tabular}{|l|l|l|l|l|}
\hline \multicolumn{2}{|l|}{ Augmented Dickey-Fuller Unit Root Test } \\
\hline Variable & T-statistic. & Critical Value & Order of Integration & Significance \\
& & & & \\
\hline BDEF & -6.831984 & -3.679322 & 1 st Difference & $1 \%$ \\
\hline REXCHR & -5.108367 & -3.679322 & 1 st Difference & $1 \%$ \\
\hline RGDPGR & -4.533283 & -3.679322 & Level & $1 \%$ \\
\hline INFLR & -5.378284 & -3.689194 & 1 st Difference & $1 \%$ \\
& & & & $1 \%$ \\
\hline RINTR & -6.576821 & -3.679322 & 1 st Difference & $1 \%$ \\
\hline RPINV & -6.292993 & -3.724070 & Level & \\
\hline
\end{tabular}

Source: E- View $7.1,2015$

Conclusively, the unit root test obtained from the Augmented Dickey - Fuller test suggests that BDEF, EXCHR, INTR, and INFLR are stationary at first difference 1(1) at 1\% level of significance, while PGDPgr and RPINV are stationary at level at $1 \%$ level of significance.

Table B. Unrestricted Cointegration Rank Test (Trace).

\begin{tabular}{|l|l|l|l|}
\hline $\begin{array}{l}\text { Hypothesized } \\
\text { No. of Ce(s) }\end{array}$ & $\begin{array}{l}\text { Trace } \\
\text { Statistics }\end{array}$ & $\begin{array}{l}0.05 \\
\text { Critical Value }\end{array}$ & Prob $^{* *}$ \\
\hline None & 113.1027 & 95.75366 & 0.0019 \\
\hline At most 1 & 67.09092 & 69.81889 & 0.0809 \\
\hline At most 2 & 31.50537 & 47.85613 & 0.6393 \\
\hline At most 3 & 15.14091 & 29.79707 & 0.7709 \\
\hline At most 4 & 7.179631 & 15.49471 & 0.7709 \\
\hline At most 5 & 0.125437 & 3.841466 & 0.7232 \\
\hline
\end{tabular}

Source: $E-$ View 7.1

\section{Test For Co-Integration}

Ho: $\beta_{1}=\beta_{2}=\beta_{3}=\beta_{4}=\beta_{4}=\beta_{5}=0$ : There is no long - run

Relationship between BDEF and macroeconomic variables

H1: $\beta_{1}=\beta_{2}=\beta_{3}=\beta_{4}=\beta_{4}=\beta_{5}=0$ : There is a long -run Relationship between BDEF Macroeconomic variables.

From Table B above, it could be seen that there exits a long -run relationship between BDEF and the macroeconomic variables; EXCHR, GDPGR, INFLR, RINTR, RPINV. Using Johanson co-integration test, Trace test indicates one(1) co-integration equation at the 0.05 level of significance, which denotes rejection of the Null hypothesis at the 0.05 level of significance. 
The Granger Causality Test Results Table C Granger Causality Pairs

\begin{tabular}{|c|c|c|c|}
\hline Causation & Obs & F-Statistic & Prob \\
\hline BDEF granger causes GDPGR & 28 & 5.46416 & 0.0114 \\
\hline GDPGR granger causes BDEF & 28 & 0.76404 & 0.4772 \\
\hline INFLR granger causes EXCHR & 29 & 0.88996 & 0.4238 \\
\hline EXCHR granger causes INFLR & 29 & 0.68835 & 0.5121 \\
\hline RINTR granger causes INFLR & 29 & 2.12769 & 0.1410 \\
\hline INFLR granger causes RINTR & 29 & 2.79739 & 0.0809 \\
\hline RINTR granger causes EXCHR & 29 & 1.47754 & 0.2482 \\
\hline EXCHR granger causes RINTR & 29 & 0.67988 & 0.5162 \\
\hline RINTR granger causes GDPGR & 28 & 2.19889 & 0.1337 \\
\hline RPINV granger causes GDPGR & 28 & 0.64252 & 0.5351 \\
\hline EXCHR granger causes BDEF & 29 & 3.07232 & 0.0649 \\
\hline BDEF granger causes INFLR & 29 & 3.35348 & 0.0520 \\
\hline BDEF granger causes RINTR & 29 & 3.45928 & 0.0479 \\
\hline BDEF granger causes RPINV & 29 & 0.81264 & 0.4555 \\
\hline EXCHR granger causes RPINV & 29 & 3.16177 & 0.0604 \\
\hline RINTR granger causes EXCHR & 29 & 1.47754 & 0.2482 \\
\hline EXCHR granger causes RINTR & 29 & 0.67988 & 0.5162 \\
\hline EXCHR granger causes GDPGR & 28 & 0.57353 & 0.5714 \\
\hline INFLR granger causes GDPGR & 28 & 4.35906 & 0.0248 \\
\hline
\end{tabular}

\section{Source: E - View 7.12015}

Here, we estimate the direction of the effect of the variables taken together as pairs. Evidently, these results indicate very strong and significant causal relationships between the variables. Four cases report bidirectional significant causal effects between the pairs of total Budget deficits (BDEF) and the Real gross domestic product growth rate (GDPGR), Inflation Rate (INFLR) and Real Exchange Rate (EXCHR), between Real Interest Rate and Inflation Rate (INFLR) as well as between Real Interest Rate (RINTR) and Real Exchange Rate (EXCHR).

There are nine cases of a one-directional effect from Real Exchange Rate (EXCHR) to Real GDP growth Rate (GDPGR), from Inflation Rate (INFLR) to Real GDP Growth Rate (GDPGR), from Real Interest Rate (RINTR) to Real GDP growth Rate(GDPGR), from Real Private Investment (RPINV) to Real GDP growth Rate (GDPGR), Real exchange rate (EXCHR to Total Budget Deficit (BDEF), from Total Budget Deficit (BDEF) to Inflation Rate (INFLR); from total budget deficit (BDEF) to Real Interest Rate (RINTR); from total budget deficit (BDEF) to Real Private Investment (RPINV).

Finally, from Real Exchange Rate (EXCHR) to Real Interest Rate (RINTR) within the period of the study, 1980 $-2013$

\section{Hypotheses Testing}

In carrying out the tests, due consideration is given to the two strands of this study. On one hand, we tested the impact of budget deficits on economic growth in Nigeria while the second strand seeks to determine 
the influence of budget deficit on each of the selected macroeconomic variables namely real interest rate, inflation rate, real private investment and real exchange rate, employing two-stage least square regression approach.

\section{Result of the Long-Run ARDL Model BDEF}

Table D, Result of the Global Statistics for the influence of Budget Deficits on macroeconomic variables in Nigeria.

Two Stage Least Square Instrument Specification: BDEF, GDPGR, EXCHR, INTR, RPIV, NFLR

TABLE, D

\begin{tabular}{|l|l|l|l|l|}
\hline Variable & Coefficient & Std Error & T-Statistic & Prob \\
\hline C & 5.999831 & 1.808579 & 3.317429 & 0.0029 \\
\hline EXCHR & -0.031282 & 0.015344 & -2.038701 & 0.0526 \\
\hline GDPGR & -0.4 .682883 & 3.232715 & -1.448591 & 0.1604 \\
\hline INFLR & 0.107064 & 0.077402 & 1.383231 & 0.1793 \\
\hline RINTR & 0.11278 & 0.083422 & 1.333918 & 0.1948 \\
\hline RPINV & $-2.97 \mathrm{E}-05$ & 0.446107 & Mean Dependent Var & 0.4893 \\
\hline R- Squared & 0.330712 & S. D, dependent var & 4.947667 \\
\hline Adjusted R - squared & 3.109933 & Sum squared resid & 3.801409 \\
\hline S. E. of Regression & 3.865929 & Durbin - Wastson stat & 232.1204 \\
\hline F - statistic & 0.010357 & Second - Stage SSR & 1.362785 \\
\hline Prob (F -statistic & 24.00000 & Instrument rank & 232.1204 \\
\hline J - statistic & 0.000001 & & 7 \\
\hline Prob (J - statistic & \multicolumn{5}{l}{} \\
\hline
\end{tabular}

Source: E View 7.12015

The Long -Run Coefficient Estimate Analysis

The estimates obtained from Table 4.4 for long-run coefficient estimate analysis indicate the existence of longrun relationship between BDEF and GDPGR, EXCHR, INFLR, RINTR, RPINV.

$\beta_{0}=5.999831$; this is the intercept of the regression line equation. The result shows a positive sign; this means that if Budget deficit is 5.999831, real exchange rate, real gross domestic product growth rate, inflation rate, real interest rate and real private investment are stable at the level. But when the amount of budget deficit changes at this level these macroeconomic variables are affected positively or negatively as the case will be.

$\mathrm{B}_{1}=-0.031282$; this is the first slope of the regression line of the real exchange rate. The result shows that there is an inverse relationship between budget deficit and real exchange rate in Nigeria. This implies that a percentage increase in budget deficit will bring a corresponding decrease of real exchange rate by 0.031282 . This result is not in line with economic expectation.

$\beta_{2}=-0.4 .682883$; this is the second slope of the long -run regression line of real gross domestic product growth rate. The result shows that there is a negative or inverse relationship between budget deficit and real gross domestic product growth rate in Nigeria. The implication is that if there is a percentage increase in budget deficit, it will lead to a decrease of 4.682883. This is not in line with economic expectation.

$\beta_{3}=0.107064$; this value represents the slope of inflation rate. The result of the long -run estimate shows that budget deficit has a positive effect on inflation rate in the economy. The result violates the theoretical expectation. This indicates that a percentage increase in the level of budget deficit will bring about a corresponding increase in inflation rate to the tune of 0.107064 .

$\beta_{4}=0.111278$; this is the fourth slope of the long -run regression estimate of real interest rate. The result shows that in the long -run, budget deficit has a positive effect on real interest rate. This is in line with our theoretical expectation. If there is a percentage increase in budget deficit, this will result in corresponding increase in real 
interest rate in Nigeria by 0.111278 . This means that large budget deficit will result in high interest rate which in turn crowds out private investment.

$\mathrm{B}_{5}=-2.97 \mathrm{E}-05$. This is the slope of real private investment. There is long-run negative or inverse relationship between budget deficit and real private investment. This implies that a percentage increase of budget deficit will result in corresponding decrease in real private investment in Nigeria by $-2.97 \mathrm{E}-05$. This confirms that large budget deficits crowds - out private investment.

Table E: Results of Global Statistics for the Influence of Budget Deficits on macroeconomic variables

\begin{tabular}{|l|l|l|l|l|l|}
\hline $\begin{array}{l}\text { Variable:t } \\
\text { Statistic }\end{array}$ & GDPGR & EXCHR & RPINV & INFLR & RINTR \\
\hline Coefficient & -4.682883 & -0.031282 & $-2.97 \mathrm{E}-05$ & 0.107064 & 0.111278 \\
\hline Standard Error & 0.188311 & 38.10073 & 14641.48 & 18.46214 & 7.514243 \\
\hline T -Statistic Calc. & -1.448591 & -2.038701 & -0.702293 & 1.383231 & 1.333918 \\
\hline T-Stat. Tab 1\% & 2.79 & 2.79 & 2.79 & 2.79 & 2.79 \\
\hline T-Stat. Tab 5\% & 2.06 & 2.06 & 2.06 & 2.06 & 2.06 \\
\hline R-Squared & 0.5311865 & 0.627721 & 0.487105 & 0.121040 & 0.837574 \\
\hline Adj R -Squared & 0.434337 & 0.570447 & 0.430117 & 0.023377 & .819526 \\
\hline S. E. of regre. & 0.188311 & 38.10073 & 14641.48 & 18.46214 & 7.514243 \\
\hline Sum of sq. res. & 0.851068 & 37743.30 & $5.79 E+09$ & 9202.968 & 1524.524 \\
\hline Log likelihood & 10.86875 & -154.1080 & -339.1858 & -132.2332 & -104.3666 \\
\hline F- statistic & 5.453459 & 10.96002 & 8.547452 & 1.239369 & 46.40972 \\
\hline Prob (f statistic) & 0.001721 & 0.000024 & 0.000375 & 0.314812 & 0.000000 \\
\hline Mean dep. Var & 0.257540 & 54.31994 & 9390.103 & 21.00968 & -0.810323 \\
\hline S.D. dep. Var & 0.250379 & 58.13330 & 19395.11 & 18.68180 & 17.68798 \\
\hline Akaike inf. Crite & -0.324584 & 10.26503 & 22.14102 & 8.789236 & 6.991392 \\
\hline Schwarz crite & -0.044344 & 10.49632 & 22.32605 & 8.974266 & 7.176422 \\
\hline Hannan-Qui. Cri & -0.234933 & 10.34043 & 22.20134 & 8.849551 & 7.051707 \\
\hline Durbin-Watson & 2.284920 & 0.945272 & 0.880301 & .936179 & 1.489210 \\
\hline NB:
\end{tabular}

NB: $* * *=$ significance at $1 \% ; * *=$ significant at $5 \% ; \mathrm{NS}=$ Not significant. $\mathrm{t}-$ ratio DF $(25) ; 1 \%=2.79,5 \%$ $=2.06$.

Source: E - Views 7.1 Statistical Package.

Table 4.5 above shows the results of the global statistics as produced under the models with two stage least square (2SLS) properties of the estimate.

Test of Model Significance - ANOVA

\begin{tabular}{|l|l|l|l|l|l|}
\hline Variable:t Statistic & GDPGR & EXCHR & RPINV & INFLR & RINTR \\
\hline T-Statistic Calc. & -1.448591 & -2.038701 & -0.702293 & 1.383231 & 1.333918 \\
\hline T-Stat. Tab 1\% & 2.79 & 2.79 & 2.79 & 2.79 & 2.79 \\
\hline T-Stat. Tab 5\% & 2.06 & 2.06 & 2.06 & 2.06 & 2.06 \\
\hline
\end{tabular}

\section{Decision Rule}

If the F-Ratio calculated is greater than F- Ratio critical at $1 \%$ or $5 \%$ level of significance, we reject Null Hypothesis (Ho). But if F-Ratio calculated is less than F-Ratio critical at $1 \%$ or $5 \%$ level of significance, we accept the Null Hypothesis

\section{Test of Hypothesis 1}

$\mathbf{H}_{\mathbf{0} 1}$ : The level of budget deficit does not affect economic growth in Nigeria.

In order to confirm the specification status of our model, we employ the analysis of variance, ANOVA.

From the ANOVA table above, since the F -Ratio calculated (5.453459) > F- Ratio critical $(3.86,2.60)$, at both $1 \%$ and $5 \%$ levels of significance respectively, we therefore reject Null Hypothesis (Ho) and conclude that budget deficits do affect the level of economic growth in Nigeria. 
$\mathbf{H}_{\mathbf{O} 2}$ : The level of budget deficit does not significantly affect the level of interest rate in Nigeria.

Since the F -Ratio calculated (46.40972) > F- Ratio critical $(3.86,2.60)$,at both $1 \%$ and 5\% levels of significance respectively, we therefore reject Null Hypothesis (Ho) and conclude that budget deficits do affect the level of real interest rate in Nigeria.

$\mathbf{H}_{\mathbf{O} 3}$ : The level of budget deficit does not significantly affect the level of Investment in Nigeria.

In order to confirm the specification status of our model, we employ the analysis of variance, ANOVA.

Since the F -Ratio calculated $(8.547452)>$ F- Ratio critical $(3.86,2.60)$,at both $1 \%$ and $5 \%$ levels of significance respectively, we therefore reject Null Hypothesis (Ho) and conclude that budget deficits do affect the level of investment in Nigeria.

$\mathbf{H}_{\mathbf{O} 4}$ : The level of budget deficit does not significantly affect inflation rate in Nigeria.

In order to confirm the specification status of our model, we employ the analysis of variance, ANOVA.

Since the F -Ratio calculated (1.239369) < F- Ratio critical $(3.86,2.60)$,at both $1 \%$ and $5 \%$ levels of significance respectively, we therefore accept Null Hypothesis $\left(\mathrm{H}_{\mathrm{o}}\right)$ and conclude that budget deficits do not affect inflation rate in Nigeria.

$\mathbf{H}_{\mathbf{O} 5}$ : The level of budget deficit does not significantly affect the level of exchange rate in Nigeria.

Since the F -Ratio calculated (10.96002) > F- Ratio critical (3.86, 2.60), at both $1 \%$ and 5\% levels of significance respectively, we therefore reject Null Hypothesis $\left(\mathrm{H}_{\mathrm{o}}\right)$ and conclude that budget deficits do affect exchange rate in Nigeria.

Testing the Level of the Significance of the Relationship of Budget deficits on GDPGR, EXCHR, INFLR, RPINV, RINTR

From table above, it could be observed that all the $\mathrm{t}$ - statistic calculated are less than all the $\mathrm{t}$ - statistic tabulated both at $1 \%$ and $5 \%$ level of significance, which indicates that the budget deficits have not adequately affected the macroeconomic variables in Nigeria, namely, real gross domestic product growth rate, real exchange rate, inflation rate, real private investment, and real interest rate.

\section{Discussion of Results}

Here, also as was the case under the hypotheses testing, due attention is equally given to the hypotheses tested in the study. These are the budget deficits and economic growth model, on one hand, and the macroeconomic variables and budget deficit models, on the other hand. All the five hypotheses were evaluated.

It is equally instructive to note that the estimation was carried out under two stage least square regression estimation models since they provide evidence of "best fit" statistics as reflected under the tables for global statistics (see tables D and E).

\section{The Budget Deficit and Economic Growth Model}

As presented in model 1of tables D and E, the model indicates that there is a significant relationship between budget deficit and economic growth of Nigeria. This model was statistically significant at $1 \%$. Also, the study, with an $\mathrm{R}^{2}$ of about $53.19 \%$, is indicative of the fact that the variations in the budget deficits have been able to explain about $43.43 \%$ of the total variation in the level of economic growth within the study period, 1980-2012.

\section{The Budget Deficit and Interest Rate Model}

The variables of the model for the real interest rate effect of budget deficit analysis is presented in D and E. Here, too, the study revealed that a significant relationship exists between budget deficit and real interest rate in Nigeria, even at $1 \%$ level of significance. However, the study, with an $\mathrm{R}^{2}$ of about $83.76 \%$, is indicative of the fact that the variations in the financial development indicators have been able to explain about $81.95 \%$ of the total variation in the level of interest rate.

\section{The Budget Deficit and Inflation Rate Model}

As presented in tables $\mathrm{D}$ and $\mathrm{E}$, the model indicates that there is a significant relationship between budget deficit and the inflation rate in Nigeria. This model was also statistically significant at $1 \%$. Also, the study, with an $\mathrm{R}^{2}$ 
of about $12 \%$, is indicative of the fact that the variations in the budget deficit financing indicators have been able to explain only about $2 \%$ of the total variation in the inflation rate of Nigeria within the study period, 19802010.

\section{The Budget Deficit and Investment Model}

As presented in tables D and E, the model indicates that there is a significant relationship between budget deficit and the level of investment in Nigeria. This model was statistically significant at $1 \%$. Also, the study, with an $\mathrm{R}^{2}$ of about $48.71 \%$, is indicative of the fact that the variations in the deficit financing have been able to explain about $43 \%$ of the total variation in the level of investment within the study period, 1980-2012.

\section{The Budget Deficit and Exchange Rate}

As presented in tables D and E, the model indicates that there is a significant relationship between budget deficit financing and the level of exchange rate in Nigeria. This model was also statistically significant at $1 \%$. Also, the study, with an $\mathrm{R}^{2}$ of about $62.77 \%$, is indicative of the fact that the variations in the budget deficit financing has been able to explain only about $57 \%$ of the total variation in the level of exchange rate in Nigeria within the study period, 1980-2012.

\section{Summary, Conclusion and Recommendations}

\section{Summary}

This study empirically investigated the effect of budget deficit on the economic growth as well as selected macroeconomic variables in Nigeria, with the following findings made;

i. There is a significant negative relationship between budget deficit and economic growth in Nigeria. This agrees with the work of Iya, Aminu and Gabdo (2014). A major policy implication of this result is that policy makers should make necessary effort to instill financial disciple among political office holders.

ii. There is a significant relationship positive between budget deficit and the level of interest rate in Nigeria;

iii. There is a significant negative relationship between budget deficit and the inflation rate in Nigeria;

iv. There is a significant negative relationship between budget deficit and the level of investment in Nigeria. This implies that budget deficit financing crowds private investment in Nigeria. This finding is in agreement with the findings of Akpokodje (1998); Paiko (2012); Ezeabasili and Nwakoby (2013); Edeh and Obi (2014); Albatel (2004) in Saudi Arabia.

v. There is a significant negative relationship between budget deficit and exchange rate in Nigeria;

\section{Conclusion}

On the basis of our findings, the study therefore, concludes that there is significant relationship between budget deficits and macroeconomic variables in Nigeria. While Budget deficits have significant negative relationship with gross domestic product growth rate, real exchange rate, real private investment, inflation rate, it has significant positive relationship with the real interest rate.

\section{Recommendations}

This study, therefore, on the basis of the above findings and conclusions, offers the following recommendations;

i. As large budget deficit pushes up interest rates, government should minimize the amount of deficits injected in the economy so as not to crowd - out private investment.

ii. Since budget deficits have not enhanced the level of economic growth expected in Nigeria, the government should endeavour to have a balanced budget. This will enable her manage available resources.

iii. If budget deficits should be used, it should be properly managed and channeled into productive sectors that will boost the economic growth.

iv. For the nation to achieve and maintain sustainable long - run economic growth, monetary policy should be used to complement fiscal policy so as to curtail inflation when budget deficit is used as policy instrument.

v. The findings of this study revealed that budget deficit financing crowds out private investment.

vi. It is recommended that for budget deficit financing to crowd in private investment in Nigeria, there should beefficient management of resources by those in authorities in Nigeria. Government should minimize the use of budget deficit in order to crowd - in private investment. 
vii. The government should monitor how these budget deficits are being utilized the impact on growth have minimal impact on the economy.

viii. Borrowed funds should be channeled to the objectives for the borrowing. This will ensure returns on such investment. Budget deficit financing should be monitored and attached to specific projects so as to be accounted for.

ix. For more than 32 years, Nigeria has embarked on budget deficit financing and this has become a tradition. It is recommended that a limit should be put to it since excessive borrowing pushes up interest rate and crowds out private investment.

\section{References}

[1] Adam, C.S and Bevan, D.L (2014), "Fiscal Deficits and Growth in Developing Countries", Journal of Public Economics, Vol. 89, Pp 511-597.

[2] Adamson, Y.K. (2000). "Structural Disequilibrium and Inflation in Nigeria: A Theoretical and Empirical Analysis". Center for Economic Research on Africa New Jersey 07043: Montclair state University, Upper Montclair.

[3] Adeniyi, J. A. (2014). The effect of Budget Deficit on Investment in Nigeria: An Empirical Study, the IUP of Applied Economics, Vol. XIII, No. 2, April 2014, pp. $38-47$.

[4] Adeoye, T. (2002), Economic Policy Shift, Agro-Climatic Conditions and Inflation in Nigeria, NISER Monograph Series, No. 7, Nigerian Institute of Social and Economic Research, Ibadan

[5] Adeyusi, O.O and Falowo, E (2013), "Impact of Fiscal Deficit Financing on Macroeconomic Growth in Nigeria", International Journal of Research in Management, Issue 3, Vol. 5, ISSN 2249-5908.

[6] Aliyu, R.U.S and Englama, A. (2009), "Is Nigeria Ready for Inflation Targeting?" Journal of Money, Investment and Banking, pp 2744.

[7] Anyanwu, J.C (2002), The Structure of the Nigerian Economy, Lagos, Joanne Educational Publishers.

[8] Appah, E and Chigbu, E.E (2013), "Impact of Macroeconomic Variables on Government Budget Deficit in Nigeria: 1981-2010", Journal of Economics and Sustainable Development, Vol. 4, ISSN 2222-2855.

[9] Arikawe, A (2002), Budget 2002 and the Challenge of Domestic Debt, Paper Presented at Lagos Business School.

[10] Aron, J. and Muellbauer J. (2000). "Inflation and Forecasting for South Africa: etaryTransmission Implications". Centre for the study of African Economies. CSAE Working Series. 2000-23. December.

[11] Audu, N.P (2012), "The Impact of Fiscal Policy on the Nigerian Economy", International Review of Social Sciences and Humanities, Vol. 4, No. 1, Pp. 142-150.

[12] Awe, A.A and Shina, O.S (2012), "The Nexus between Budget Deficit and Inflationary in the Nigeria Economy (1980-2009), "Research Journal of Finance as Accounting, Vol. $\quad 3$, No. 10, Pp 78-92.

[13] Bello, Y.A (2003), Fiscal Adjustment and Issues of Capital Expenditure, CBN Bullion, Vol. 27, No. 3.

[14] Boussard, J, de Castro, F and Salto, M (2012),"Fiscal Multipliers and Public Debt Dynamics in Consolidations" European Economy Economic Papers, No. 460 .

[15] Brauninger, M. (2002). “The Budget Deficit, Public Debt and Endogenous Growth; Journal of Economics, Vol. 63

[16] Catao, L and Terrnnes, M. (2001), Fiscal Deficits and Inflations: A New look at Emerging Market Evidence, IMF Working Paper, WP/01/74.

[17] CBN (2000), “The Changing Structure of the Nigerian Economy and Implications for Development" Realm Communications Ltd, Lagos.

[18] Cebula, R.T (2000), Impact of Budget Deficits on Ex-past Real Long Term Interest Rates, Applied Economics Letters, 7(3): 77-79.

[19] Chakroborty, P and Chakraborty, L.S (2006), "Is Fiscal policy Contracycical in India? An Empirical Analysis, National Institute of Public Finance and Policy, New Delhi, Centre for Development Studies (JNU).

[20] Chaudhay, M.A and Sgabbir, G (2005), Macroeconomic Impacts of Budget Deficit on Pakistan's Foreign Sector. Pakistan Economic and Social Review, XLIII, No. 2 (Writer 2005) PP 185-198.

[21] Chima, M. (2014), “Budget Deficit-Economics” httpllmartinblibrary.com/2012/12,culled 20/6/14.

[22] Chimobi, O.P and Igwe, O.L (2010), "Budget Deficit, Money Supply and Inflation in Nigeria”, European Journal of Economics, Finance and Administrative Sciences, 19:52-60.

[23] Chowdhury, M.K (2005), Deficits Financing in LCDS: Evidence from South Asia, Middle East Business and Economic Review, 17 (1), $58-69$.

[24] Cottardli, C and Jaramillo, L. (2012)," Working Hand in Hand: Fiscal Policy and Growth in Advanced Economics, INF Working Paper, No. 12/137. 
[25] Dalyop, G.I (2010),'Fiscal Deficits and the Growth of Domestic out in Nigeria”, Jos Journal of Economics, 4(1)

[26] Doménech, R., D. Taguas and J. Varela (2001): “The Effects of Budget Deficit on National Saving in the OECD”, Economics Letters, vol. 91, n. 2, pp. 323-327.

[27] Eicher, T. and S.J. Turnovsky (2001): “Transition Dynamics in Non-Scale Models", Journal of Economic Dynamics and Control, vol. 25 , pp. $85-113$.

[28] Essien E.A. (2005). "Exchange Rate Pass-Through to Inflation in Nigeria”. West African Journal of Monetary and Economic Integration (First Half), Volume 5, Number I, Accra: West African Monetary Institute.

[29] Ezeabasiti, V.N; Tsegba, I.N and Ezi-Herbert, W. (2012), "Economic Growth and Fiscal Deficits: Empirical Evidence from Nigeria", Economics and Financial Review, Vol. 2 (6) Pp 85-96.

[30] Fakiyesi, O.M (1996), "Further Empirical Analysis of Inflation in Nigeria" Central Bank of Nigeria Economic and Financial Review, 34 (1)I 489-500.

[31] Gale, W.G and Peter, O. (2003), "Economic Effects of Sustained Budget Deficits” National Tax Journal Vol. 56, No. 3, Pp. 463485.

[32] Gebhard, K and Silika, P (2006), "Sustainability of Crisis Fiscal Policy" LESIFO Working Page 168 (5), Switzerland, University of St. Golden.

[33] Gemmel, N. (2001), Fiscal Policy in a Growth Framework, World Institute for Development Economic Research, Discussion Paper No, 2001/84, Pp 1-29.

[34] Ghartey, E (2000), Macroeconomic Instability and Inflationary Financing in Ghana, Economics Modeling, 18:415-433.

[35] Hansson, I. and C. Stuart, 1987, “The Welfare Costs of Deficit Finance”, Economic Inquiry, Vol. 25, nº 3, pp. 479-496.

[36] Iyoha, M (2002), "Budget of Economic Growth and Development", Bullion Publication of Central Bank of Nigeria, Vol. 6. No.2.

[37] Jhingan, M.L (2004), Macroeconomic Theory (11 ${ }^{\text {th }}$. Ed), New Delhi, Vrinda Publications (P) Ltd.

[38] Kanas, G. (1994), "Macroeconomic Effects of Budget Deficit: Further International Evidence" Journal of International Money and Finance, 13(2): 199-210.

[39] Keho, Y. (2010), "Budget Deficits and Economic Growth: Causality Evidence and Policy Implications for WAEMU Countries", European Journal of Economics, Finance and Administrative Sciences, 18:99-105.

[40] Khan, M.S. and Schimmelfenig, A. (2006). "Inflation in Pakistan: Money or Wheat?". IMF Working Paper,WP/06/60, Middle East and Central Asia Department, March.

[41] Medee, P. N and Nenbee (2012), “The Impact of Fiscal Deficit on Inflation in Nigeria between 1980 and 2010", International Journal of Economic Development, Research and Development, Vol. 3, No. 1.

[42] Molarty, R.K (2012), "Fiscal Deficit-Economic Growth in India: A Co-Integration Analysis", Centre for Economic Studies and Planning, school of Social Sciences, Jawaharial Nehru University, New Delhi, 110067.

[43] Nenbee, S. G. (2009), A Comparative Analysis of Fiscal Deficits and Inflation Dynamics in Nigeria under Regulation and Deregulation, EVP Multi-Disciplinary J Journal of Public Policy and Contemporary Issues, 2(2\&3): 38-45.

[44] Nenbee, S.G and Dubon, P.B (2005), “Output Inflation Relationship in Nigeria: Lessons from Petroleum Management Studies and Policy, (JEMSAP), 2(10), 17-32.

[45] Nurudeen, A and Usman, A. (2010), Government Expenditure and Economic Growth in Nigeria, 1970- 2008: A Disaggregated Analysis", Discussion and Economic Journal Vol. 20, BEJ-4.

[46] Nwaogwugwu, I.C (2005), Public Expenditure and Fiscal Deficits in Nigeria in Fakiyesi, O.O and Economic Management in Nigeria, Lagos University of Lagos.

[47] Nzotta, S.M (2004), Money, Banking and Finance: Theory and Practice, Owerri, Hudson-Jude publishers.

[48] Obadan, M. (2001), "Monetary Policy and Domestic Debt Management", in Chris Itsede and Sunday Owualah (eds), Domestic Debt Management, WAIFEM Lagos.

[49] Obaden, M. (2011), External Sector Polices in Fiscal Budget National Center for Economic and Management Administration (NCEMA) Policy Analysis Series, Vol. 1, No. 5.

[50] Odhiambo, O.S, Momanyi, G. Othuon, L and Aila, F.O (2013) "The Relationship between Fiscal Deficits and Economic Growth in Kenya: An Empirical Investigation” Greener Journal of Sciences Vol. 3 (6) Pp 306-323.

[51] Odionye, J.C and Uma, K.E (2013), "The Relationship between Budget Deficit and Interest Rate: Evidence from Nigeria", European Journal of Business and Social Sciences, Vol. 2, No. 1, PP 158-167.

[52] Odusola, A. F. and Akinlo, A. E. (2001). "Output, Inflation, and Exchange Rate in Developing Countries: An Application to Nigeria". The Developing Economies, June. 
[53] Ojo, M.O. (2000). "The Role of the Autonomy of the Central Bank of Nigeria (CBN) In promoting Macroeconomic Stability “.Central Bank of Nigeria Economic and Financial Review, Volume 38, Number, 1 March.

[54] Olonola, P.A and Olagunju, M.A (2004), Fiscal Deficit and Private Consumption Behavior in Nigeria (1970-2001), The Journal of Economics, 84(335): 597-607.

[55] Oluwatobi, S.O and Ogunrinola, I.O (2011), "Government Expenditure on Human Capital Development: Implications for Economic Growth in Nigeria", Journal of Sustainable Development, Vol. 4, No. 3.

[56] Omoniyi, O.S, Olasunkami, O.I and Babatunde, O.A (2012), "Empirical Analysis of Twins” Deficits in Nigeria, J.J MBS Vol. 2, Issue 3, ISSN 2230-9519.

[57] Onuorah, A. C and Odita, A.O (2013), Relationship between Macro-Economic Variables and Budget Deficit, International Journal of Management Sciences, vol. 1, No. 10,416-426.

[58] Osiegbu, P.I and Onuorah, A.C (2011), Fundamentals of Finance” C.M Global Co.Ltd, Cable Point Asaba, Delta State.

[59] Osiegbu, P.I, Onuorah, A.C and Nnamdi, I (2010), Public Finance: Theory and Practice, Asaba.

[60] Osuka, B.O and Achinihu, J.C (2014), The Impact of Budget Deficits on Macro-Economic Variable in the Nigerian Economy (19812012)". International Journal for Innovation Education and Research Vol. 2, 2014, www.ijier.net.

[61] Otu, M.F (2006), Imperative of National Savings: A Case for Adoption of Appropriate Benchmark Price for Crude Oil, CBN Bullion, $30(11)$.

[62] Sahan, F and Beletasogh, T (2011), “A Parcel Co-integration Analysis of Budget Deficit and Inflation for EU Countries and Turkey

[63] Sanusi, J.O (2003), "Fiscal Policy Management in Nigeria" Paper Delivered at Seminar of the Nigerian Economic Society held on 5/22/2003 at Muson Center, Lagos.

[64] Taiwo, M and Abayomi, I. (2011), "Government Expenditure and Economic Development: Empirical Evidence from Nigeria", European Journal of Business and Management, Vol. 3, No1.

[65] Turnovsky, S.J. (2000a): "Fiscal Policy, Elastic Labor Supply and Endogenous Growth", Journal of Monetary Economics, Vol. 45, No. 1, pp. 185-210.

[66] Ukeje, E.U; Essien, S.N, Yakubu, M.U and Akimboye, L (2004), Critical Issues in Finance, Investment and Growth in Nigeria, in CBN Finance, Investment and Growth in

Nigeria, Nnanna, O.J; A Englama, and F.O Odoko (ed), Pp 69-94.

[67] Umaru, A. D and Gatawa, A. U (2014) "Fiscal Deficit and Economic Growth in Nigeria (1970-2011): A Disaggregated Approach" Journal 12, ISSN 1596-8308.

[68] Williams, O. and Adedeji, O.S. (2004). Inflation Dynamics in the Domincan Republic". IMF Working paper, WP/04/29, Western Hemisphere Department: Washington, D.C., February.

[69] World Bank (2002), The Choice between External and Domestic Debt in Financing Budget Deficits: The Case of Central and West African Countries, African Department and Policy Development and Review Department.

[70] Wosowii, E (2013), Fiscal Deficits and Macroeconomic Aggregates in Nigeria: Kuwait Chapter of Arabian Journal of Business and Management Review, Vol. 2, No.9. 